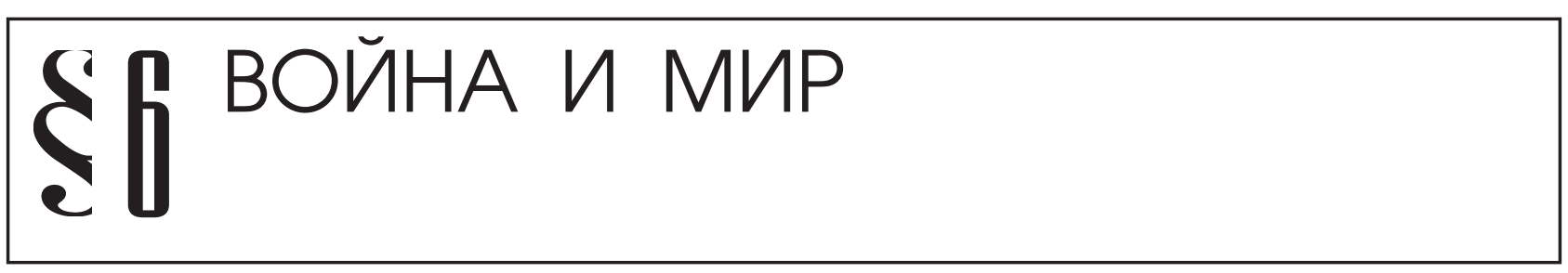

Самохин К.В.

\title{
МОДЕРНИЗАЦИЯ РОССИЙСКОЙ ИМПЕРИИ В НАЧАЛЕ ХХ ВЕКА
}

\begin{abstract}
Аннотация: Статья посвящена исследованию военного фактора как механизма российской модернизации в начале ХХ века. Основная щель - анализ влияния русско-японской войны 1904-1905 г2. на переход Российской империи от аграрного общества к индустриальному. Акцентируется внимание на необходимости органичности модернизационных прочессов в России как залоге их успешной реализаиии. Научной новизной работы является интерпретаиия войны как своеобразного «Вызова» к российской (славянской) иивилизаиии, «Ответом» на который стала модернизаиия Российского государства в указанный период. Главным выводом является положение о том, что война между Россией и Японией в начале прошлого столетия способствовала продолжению основных тендениий российской модернизации, сложивиихся в XVIII-XIX веках. Наиболее актуальными стали прочессы в политической и соииальной сферах, экономическая модернизация во внутренней политике Николая II при этом отошла на второй план, а духовная находилась в зачаточном состоянии.
\end{abstract}

Review: The article is devoted to studying the military factor as the mechanism of the Russian modernization in the early XX century. The main purpose of research is to analyze the influence of the Russo-Japanese war of $1904-1905$ on the transition of the Russia Empire from the agrarian society to the industrial society. Special emphasis is made on the need for harmonized modernization processes in Russia as the key to their successful implementation. The scientific novelty of research is the interpretation of war as some kind of a Challenge for the Russian (Slavic) civilization. Modernization of the Russian Empire of that period was the Response to that challenge. The main conclusion made by the author is the statement that the war between Russia and Japan at the beginning of the last century contributed to the development of the main tendencies in the Russian modernization that had been formed in the XVIII-XIX centuries. Political and social processes came to the fore while the economic modernization as the part of the internal policy established by Nicolas the Second became secondary and spiritual modernization was not even properly developed.

Ключевые слова: Первая русская револючия, военный фактор, органичность российской модернизации, механизм российской модернизации, Япония, русско-японская война, Россия, модернизация, дуалистическая монархия, стольпинская аграрная реформа

Keywords: the First Russian Revolution, military factor, limits of the Russian modernization, mechanism of the Russian modernization, Japan, Russo-Japanese war, Russia, modernization, dual monarchy, Stolypin agrarian reform.

$\mathrm{T}$ Теория модернизации, набирающая всё большую популярность в отечественных гуманитарных науках, начиная с рубежа 80-х - 90-х гг. $\mathrm{XX}$ века, постепенно теряет свой преимущественно прикладной характер: российские философы, историки, социологи и политологи переходят к более высокому уровню её теоретического осмысления. К окончанию периода «перестройки» дискуссионность обозначенной теории подогревалась необходимостью смены исторического мировоззрения, так как формационный подход к истории перестал полностью удовлетворять отечественных учёных, и они оказались на перепутье выбора новой исторической парадигмы ${ }^{1}$. Дополнительный интерес к указанной теории вызвала политическая стратегия, выбранная В. В. Путиным на второй срок своего президентства ${ }^{2}$.

\footnotetext{
${ }^{1}$ Самохин K. B. Северная война: первый опыт российской модернизации // Исторические, философские, политические и юридические науки, культурология и искусствоведение. Вопросы теории и практики. Тамбов: Грамота, 2011. № 8 (14). С. 180.

${ }^{2}$ Модернизация России и Европа: материалы круглого стола, проведенного 18.03.2004. URL: http://www.zlev.ru/41_40.htm.
} 


\section{Политика и общество 1 (109) • 2014}

Однако с того момента прошло уже почти десять лет: при этом очевидно, что процесс реформирования в Российской Федерации имеет достаточно противоречивые результаты. Наметившаяся тенденция приводит к желанию российских учёных-гуманитариев найти причины столь неоднозначного продвижения Российского государства по пути модернизации. Именно поэтому осмысление обозначенной теории неуклонно переходит в теоретическую плоскость.

Доказательством всему выше сказанному является рассмотрение модернизации рядом историков и социологов не с позиций противопоставления «традиция - модернизация», а с точки зрения более сложной конструкции «архаика - традиция - модернизация», где «традиция» является промежуточным элементом, испытывающим давление как со стороны «архаики», так и со стороны «модернизации»³. Между тем, учёные, анализирующие модернизацию через такую призму, приходят к итоговому выводу о том, что конечной целью на этом пути является «модерн - в лице демократического и правового государства, становящегося гражданского общества, развивающейся рыночной экономики» ${ }^{4}$. Надо заметить, что в качестве основного примера в данном случае выступает Япония, которая, сохранив традиции в духовной сфере, сумела сделать модернизационный рывок в социально-экономическом и политическом планах, и это позволяет говорить о так называемой «консервативной модернизации» ${ }^{5}$.

Подобный вывод относительно японской модели модернизации не является открытием 80-х - 90-х гг. ХХ века. Известный военный историк А. А. Керсновский, издавший ещё в 30-е гг. прошлого века свой знаменитый труд «История русской армии», писал: «Подобно России за два столетия до того, Япония заимствовала западную цивилизацию. Однако Мутсухито не повторил роковой ошибки Петра I. Он бережно отнёсся к

\footnotetext{
${ }^{3}$ Буранчин А. М. Традиционное общество и модернизация: теоретико-методологический аспект. URL: http://againstpostmodern.org/buranchin-traditsionnoe-obshchestvo-i-modernizatsiya-teoretiko-metodologicheskii-aspekt; Костюк К. Н. Apхаика и модернизм в российской культуре. URL: http://www. nir.ru/sj/sj/sj3-4-99kost.html.

${ }^{4}$ Костюк $К$. Н. Архаика и модернизм в российской культуре.

${ }_{5}^{5}$ Буранчин А. М. Традиционное общество и модернизация: теоретико-методологический аспект.
}

духовному лику своего народа, его самобытности, его древним обычаям и не насиловал его души слепым и варварским поклонением всему иностранному. Взяв от Европы цивилизацию, японцы сохранили свою культуру. Они ревниво отстояли своё японское естество, свою духовную цельность и не уродовали их на голландский, французский или немецкий образец. В этом отношении преобразователя Японии следует поставить выше полтавского победителя» ${ }^{6}$.

Данная статья - ещё один вариант анализа российской модернизации на основе конкретного исторического материала. В ней выявляются причины затяжного характера отечественных модернизационных процессов, что, возможно, позволит сделать коррекцию выбранной в 2000-е гг. стратегии государственного развития, а также вывод о её применимости/неприменимости к российским реалиям.

Сам термин «модернизация» понимается нами как переход от аграрного общества к индустриальному, который носит комплексный характер и имеет место во всех сферах жизнедеятельности общества: в экономике намечаются основы построения рыночной системы и индустриализация; в социальной сфере присутствуют рост социальной мобильности и урбанизация; в политике происходит складывание гражданского общества и правового государства; духовная сфера характеризуется возникновением мультикультурализма, базирующегося на общечеловеческих ценностях ${ }^{7}$.

Основным фактором, который предопределил вступление России на путь модернизационных преобразований и постоянно удерживал её в данном русле на протяжении XVIII-XX веков, были войны. Последние играли, если мы воспользуемся терминологией А. Дж. Тойнби, роль «Вызова» к российской (славянской) цивилизации в указанном аспекте ${ }^{8}$. Ярким доказательством тому

\footnotetext{
${ }^{6}$ Керсновский А. А. История русской армии в 4 томах. М.: Голос, 1992. Т. 3. С. 108.

${ }^{7}$ Модернизация России и Европа: материалы круглого стола, проведенного 18.03.2004.

${ }^{8}$ Самохин К. В. Трансформации крестьянского менталитета в годы Первой мировой войны (на материалах Тамбовской губернии) // Первая мировая война: поиски подходов к исследованию, приглашение к диалогу: Доклады Академии военных наук (военная история). № 5 (23). Саратов, 2006. С. 250-255.
} 
являются Северная, Наполеоновские и Крымская войны ${ }^{9}$.

В дополнение ко всему выше сказанному необходимо подчеркнуть, что модернизация Российской империи подчинялась логике смещения вектора модернизационных процессов от экономической сферы к духовной ${ }^{10}$ : империей в этот период, может считаться модернизационным «Вызовом». Последний будет иметь место лишь только тогда, когда соперником Российского государства на военном поприще будет уже модернизированная страна. Более того, война может считаться фактором российской модернизации в зависимости от своего характера (региональный,

\section{Экономическая доминанта \\ Социально-политическая доминанта \\ Ценностно-духовная доминанта}

Для полноты картины необходимо указать ещё одну тенденцию в развитии российских модернизационных процессов: различные революционные и социальные потрясения играли роль своеобразного «ингибитора» при переходе России от аграрного общества к индустриальному в XIX веке ${ }^{11}$.

Основной целью данной статьи является анализ модернизационных процессов Российской империи начала XX века, проходящих под влиянием русско-японской войны 1904-1905 гг., в корреляции с японской моделью перехода от традиционного общества к индустриальному, исходя из заявленной концепции российской модернизации.

Россия на протяжении XVIII-XIX веков испытывала постоянное модернизационное давление со стороны европейских держав, уже прошедших к тому времени путь перехода от аграрного общества к индустриальному. Происходило это, как было сказано выше, при помощи военного фактора. Однако не любая война, ведшаяся Российской

\footnotetext{
${ }^{9}$ Самохин К. В. Модернизация Российской империи в пореформенный период // Альманах современной науки и образования. Тамбов: Грамота, 2013. № 5 (72); Самохин К. В. Процессы модернизации в послепетровской России XVIII века // Современные исследования социальных проблем (электронный научный журнал). Красноярск: Научно-инновационный центр, 2012. №9 (17). URL: http://sisp.nkras.ru/e-ru/issues/2012/9/samokhin.pdf; СамохинК.В.Процессыроссийской модернизации в конце XVIII - первой половине XIX веков // Современные исследования социальных проблем (электронный научный журнал). Красноярск: Научно-инновационный центр, 2012. №11 (19). URL: http://sisp.nkras.ru/e-ru/ issues/2012/11/samokhin.pdf; Самохин К. В. Северная война: первый опыт российской модернизации.

${ }^{10}$ Самохин К. В. Многоликая война // Исторические, философские, политические и юридические науки, культурология и искусствоведение. Вопросы теории и практики. Тамбов: Грамота, 2009. № 2 (3). Ч. 2.

${ }^{11}$ Самохин К. В. Процессы российской модернизации в конце XVIII - первой половине XIX веков.
}

регионально-континентальный, мировой) и результативности. Чем больший масштаб имеют боевые действия по числу участников и чем неудачнее военная кампания для России, тем лучше последняя следует по пути преобразований в модернизационном ключе ${ }^{12}$.

Совершив мощный рывок в данном плане во второй половине XIX века, связанный в первую очередь с отменой крепостного права, Российская империя не достигла окончательной цели модернизации под воздействием Крымской войны ${ }^{13}$. Успешная русско-турецкая война 1877-1878 гг., а также мирные инициативы Российского государства в конце XIX века (Гаагская конференция 1899 г.) не давали повода думать о возможности какого-либо крупного внешнеполитического конфликта с российским участием: «Со времени злополучной Гаагской конференции как правительство, так и общество были проникнуты усыпляющим и расслабляющим пацифизмом. О войне серьёзно не думали. В частности, не допускали и мысли о том, что она может вспыхнуть на Дальнем Востоке; всё внимание Военного ведомства при генерале Куропаткине сосредоточилось на западной границе» ${ }^{14}$.

Таким образом, Запад подготовил новый «Вызов» к российской (славянской) цивилизации совершенно с неожиданной - восточной - стороны. Приведём аргументы в пользу того, что Япония к началу XX века уже была включена в круг модернизированных западных держав.

Японская цивилизация, как и все остальные, является уникальной, потому она имеет определён-

\footnotetext{
${ }^{12}$ Самохин К. В. Трансформации крестьянского менталитета в годы Первой мировой войны (на материалах Тамбовской губернии).

${ }^{13}$ Самохин К. В. Модернизация Российской империи в пореформенный период.

${ }^{14}$ Керсновский А. А. История русской армии в 4 томах. С. 55.
} 


\section{Политика и общество 1 (109) • 2014}

ные особенности своего развития. Вот как её характеризуют известные французские востоковеды Вадим и Даниель Елисеефф: «... словно редкостная жемчужина, образованная из чужеродных элементов, это поразительное сокровище возникло из нищеты, апатии и изоляции, блистательное виде́ние, порождённое ощущением однообразия жизни и необратимости течения времени» ${ }^{15}$. Несмотря на всю афористичность приведённой выше характеристики, она в целом отражает специфику японской модели общества. «Чужеродные элементы» в данном случае - это, прежде всего, определяющее влияние Китая с его конфуцианскими, даосскими и буддистскими традициями. Но уже в VIII-IX веках Япония, быстрыми темпами преодолевая отставание от своего великого соседа, отличалась важными особенностями, которые «... были связаны с огромной ролью родоплеменной феодализирующейся знати и более явственной, нежели где-либо ещё, тенденцией к приватизации, т.е. к возрастанию роли и значения частного владения при слабости власти центра» ${ }^{16}$.

Другим «чужеродным элементом» следует признать европейское влияние, в первую очередь португальское и голландское, которое принесло с собой христианские традиции, научные открытия и технические изобретения в XVI веке. Однако и здесь необходимо отметить ещё одну важную особенность японской модели общества - восприимчивость к достижениям других цивилизаций: «Японское чудо, если уж использовать модное выражение, заключается в чрезвычайной восприимчивости этого народа, который получил столько благ из-за моря, сумел их воспринять, приспособить, но не растворить в собственной национальной сокровищнице традиций и устремлений» ${ }^{17}$.

Указанные выше особенности во многом предопределили радикальный поворот развития Японии во второй половине XIX века, известный как «реставрация Мэйдзи», и заложили основу для успешного итога модернизационных усилий. 1868 г. стал отправной точкой на этом пути, когда была уничтожена старая социальная структура японского

${ }^{15}$ Елисеефф В., Елисеефф Д. Японская цивилизация / Пер. с франц. И. Эльфонд. Екатеринбург: У-Фактория, 2005. С. 65.

${ }^{16}$ Васильев Л. С. История Востока: В 2 т. Т. 1: Учеб. по спец. «История». М.: Высш. шк., 1994. С. 435.

${ }^{17}$ Елисеефф В., Елисеефф Д. Японская цивилизация. С. 9. общества через создание широких возможностей перехода из одного социального слоя в другой, выбора профессии и формирования «совещательных собраний» ${ }^{18}$. Эта реформа была дополнена преобразованием 1872 г., по которому вводилась всеобщая воинская повинность, что подорвало позиции самурайства ${ }^{19}$.

В 1872-1873 гг. была осуществлена серия преобразований, кардинально изменивших систему аграрных отношений. Земля была закреплена за теми, кто ею реально владел, что привело к возможности для крестьян «... за не столь уж тяжелый выкуп владеть своей землёй и работать на рынок» ${ }^{20}$. Создавались благоприятные условия для развития банковского и промышленного секторов. Венчала данные преобразования конституция 1889 г., фактически установившая конституционную монархию ${ }^{21}$. В итоге Япония за 20 лет прошла путь, по которому Российская империя к тому моменту следовала уже полтора столетия. Секретом подобного успеха, по мнению ряда исследователей, является сохранение традиционных духовных ценностей, которые хорошо сочетались с модернизацией в социальной, экономической и политической сферах: «Данная модель модернизации, условно говоря, «модернизации без вестернизации», была применена и в других странах «незападного» мира. В целом типологически можно констатировать наличие сходства в содержании и характере общественных процессов периода «Мэйдзи иссин» в Японии и событиями исламской революции в Иране 1978 79 гг, а также политикой «4-х модернизаций» в современном Китае. Во всех этих явлениях можно обнаружить в большей или меньшей степени черты «консервативной модернизации»: возврат к сакральным и духовным ценностям, к традиции с одной стороны, и устремленность в будущее, технологический рывок, быстрые темпы социальноэкономической модернизации с другой» ${ }^{22}$.

Таким образом, начало ХХ века Япония встретила в качестве мощного модернизированного го-

\footnotetext{
${ }^{18}$ Елисеефф В., Елисеефф Д. Японская цивилизация. С. 104.

${ }^{19}$ Васильев Л. С. История Востока: В 2 т. Т. 2. С. 219.

${ }^{20}$ Васильев Л. С. История Востока: В 2 т. Т. 2. С. 219.

${ }^{21}$ Васильев Л. С. История Востока: В 2 т. Т. 2. С. 221.

${ }^{22}$ Буранчин A. М. Традиционное общество и модернизация: теоретико-методологический аспект.
} 
сударства, которое уже вышло в своём развитии за пределы Востока и успешно вписалось в ряд ведущих индустриально развитых стран Запада. Потому русско-японскую войну 1904-1905 гг. следует рассматривать как очередной «Вызов» западной цивилизации к российской (славянской) на пути перехода от традиционного общества к индустриальному.

Как правило, в отечественной историографии 1990-х - 2010-х гг. русско-японскую войну считают одной из причин, вызвавших Первую русскую революцию. Крупные поражения, которые потерпела «большая» Россия от «маленькой» Японии, были обусловлены в первую очередь неверно определенными политическими приоритетами, стратегическими и тактическими просчётами русского командования ${ }^{23}$. А они, в свою очередь, вытекали из общей отсталости Российской империи от Японского государства в плане результатов модернизационных мероприятий, которые проводились в тот момент в обеих странах.

Первая русская революция значительно отличалась от социальных потрясений XIX века не только в плане масштабности, но и результативности для процесса модернизации. Как было отмечено выше, различные восстания и бунты XIX столетия во многом тормозили модернизационные усилия российских императоров, а революция 1905-1907 гг. была первой, которая предопределила существенный модернизационный рывок Российского государства, но уже в начале ХХ века. И связан этот прорыв был в первую очередь с политической сферой жизнедеятельности российского общества.

Начало прошлого столетия Россия встретила в качестве абсолютной монархии, однако, начиная с периода правления Екатерины II, в политическом развитии Российского государства наметилась чётко одна тенденция: русские монархи второй половины XVIII - XIX века стремились поставить себя в определённые законодательные рамки, что можно расценивать как начало построения в Российской империи правового государства и гражданского общества ${ }^{24}$. Указанное направление развития

${ }^{23}$ Керсновский А. А. История русской армии в 4 томах. C. 22-23.

${ }^{24}$ Самохин К. В. Модернизация Российской империи в пореформенный период; Самохин К. В. Процессы модернизации в послепетровской России XVIII века; Самохин К. В. Про- в политическом плане было продолжено и в начале XX века.

Первую дату выше обозначенного процесса можно определить как 18 февраля 1905 г., когда Николай II подписал три документа: «Первый был манифестом, призывающим население помочь в восстановлении порядка. Второй представлял собой приглашение всем царским подданным подавать “предположения” “по вопросам, касающимся усовершенствования государственного благоустройства”. Последний документ был “рескриптом” Булыгину, ставящим его в известность, что царь решил “привлекать достойнейших, доверием народа облечённых, избранных от населения людей к участию в предварительной разработке и обсуждении законодательных предложений"» ${ }^{25}$. Итогом принятия этих законодательных актов стало создание так называемой «Булыгинской Думы», характеризовавшейся законосовещательными функциями. Но эта мера была уже крайне ограниченной для сложившейся в августе 1905 г. политической ситуации, потому у многих представителей тогдашнего российского общества Манифест от 6 августа 1905 г. вызвал разочарование. «Булыгинская Дума» так и не начала свою работу, что стало следствием Всероссийской октябрьской политической стачки, которая вызвала необходимость принятия нового законодательного акта, известного как «Высочайший Манифест об усовершенствовании государственного порядка» от 17 октября 1905 г. ${ }^{26}$.

Обозначенный государственный документ содержит три пункта: «Во-первых, он обещает дать свободы (слова, собраний и т.д.), во-вторых, он объявляет о предстоящей демократизации выборов в Государственную Думу, в-третьих, он придаёт Государственной Думе характер законодательного учреждения» ${ }^{27}$. Данный Манифест необходимо признать конституционным актом, несмотря на то, что он «был вырван у царя под давлением» и в нём нет слова “конституция”, так как Николай II «хо-

цессы российской модернизации в конце XVIII - первой половине ХІХ веков.

${ }^{25}$ Пайпс Р. Русская революция. Ч. 1. М.: РОССПЭН, 1994. C. 38 .

26 Леонтович В. В. История либерализма в России. 17621914. М.: Русский путь; Полиграфресурсы, 1995. С. 427.

27 Леонтович В. В. История либерализма в России. 17621914. C. 440. 


\section{Политика и общество 1 (109) • 2014}

тел избежать ненавистного слова, чтобы сохранить иллюзию самодержавия», хотя «прекрасно разбирался в существе сделанных им уступок» ${ }^{28}$. Однако указанные обстоятельства опубликования Манифеста очень важны для определения формы правления, установившейся в Российской империи в результате политических реформ 1905-1906 гг.

Ещё одно важное изменение политической системы Российского государства в начале XX века было связано с преобразованием высшего органа исполнительной власти. Речь идёт о Совете министров. С момента появления министерств по реформе государственного управления 1802 г. в России не существовало единого кабинета министров и института премьер-министерства. Российские императоры не шли на подобное преобразование, боясь ослабления своей власти ${ }^{29}$. Однако трансформации в законодательной сфере потребовали реформ и в исполнительной вертикали. В итоге 19 октября 1905 г. по указу Николая II «О мерах к укреплению единства в деятельности министерств и главных управлений» Совет министров возобновил свою деятельность в новом качестве: как единый орган управления, ответственный непосредственно перед императором и призванный в определённой степени нейтрализовать влияние Государственной Думы. Вряд ли в данном случае стоит говорить об ограничении прерогатив императора в рамках исполнительной власти, но модернизация политической системы Российского государства шла именно в таком направлении.

Следующим важным шагом на пути либерализации самодержавного монархического режима в Российской империи был выход указов «О временных правилах о повременных изданиях» от 24 ноября 1905 г. и «О временных правилах об обществах и союзах» от 4 марта 1906 г., которые де-юре упраздняли цензуру и давали возможность организовывать профсоюзы и политические партии. Подобные меры, кажущиеся на первый взгляд очень радикальными, имели свои ограничения, которые часто искажали или сводили на нет подлинный смысл указанных государственных документов ${ }^{30}$.

\footnotetext{
${ }^{28}$ Пайпс Р. Русская революция. Ч. 1. С. 54-55.

${ }^{29}$ Пайпс Р. Русская революция. Ч. 1. С. 76.

${ }^{30}$ Пайпс Р. Русская революция. Ч. 1. С. 177.
}

Наконец, одной из самых значимых трансформаций политического режима в России начала $\mathrm{XX}$ века стали подготовка и издание Основных государственных законов Российской империи в редакции от 23 апреля 1906 г. Этот законодательный акт не получил однозначной оценки в отечественной историографии и определяется подчас прямо противоположными характеристиками: от конституции - преимущественно в дореволюционный и современный этапы - до лжеконституции - в основном в советский период ${ }^{31}$.

Когда стала понятна мысль о необходимости новой редакции Основных государственных законов, возник вопрос, имевший принципиальный характер: создавать ли эти законы в сотрудничестве с Государственной Думой или осуществить данное мероприятие до начала её первого созыва? Николай II выбрал из существующей альтернативы второй вариант, так как не хотел в этом факте видеть прецедент для существования Учредительного Собрания ${ }^{32}$.

Само название первой главы Основных государственных законов - «О существе Верховной Самодержавной власти» - говорит о стремлении последнего российского императора сохранить хотя бы видимость неограниченности своего монархического правления (анализ Основных государственных законов производится по тексту, приведённому на сайте МГУ им. М. В. Ломоносова с учётом поправок, указанных во введении к нему ${ }^{33}$ ). Но слово «неограниченный» было исключено из новой редакции Законов, в отличие от предыдущих редакций (см. статью 1$)^{34}$.

Основные государственные законы написаны с учётом принципа разделения властей, вошедшего в мировую законодательную практику начиная с XVII века. Исходя из указанного принципа, власть делилась на законодательную, исполнительную и судебную. При этом явное ограничение прерогатив

\footnotetext{
${ }^{31}$ Миронов Б. Н. Социальная история России периода империи (XVIII начало XX в.): В 2 т. СПб.: Изд-во «Дмитрий Буланин», 2000. Т. 2. С. 154.

32 Леонтович В. В. История либерализма в России. 17621914. C. 441.

${ }_{33}$ Высочайше утверждённые Основные государственные законы 23 апреля 1906 г. URL: http://www.hist.msu.ru/ER/Etext/ apr1906.htm.

${ }^{34}$ Пайпс Р. Русская революция. Ч. 1. С. 178.
} 
Николая II было очевидным преимущественно в законодательной сфере. По статье 7: «Государь Император осуществляет законодательную власть в единении с Государственным Советом и Государственною Думою». Однако за ним оставались «почин по всем предметам законодательства», что фактически означало наличие у российского монарха права законодательной инициативы, и обязательное окончательное утверждение закона (статьи 8, 9). Здесь следует сказать и о возможности законодательного вето императора, которое, тем не менее, могло быть преодолено на следующей сессии Государственной Думы (глава 10, статья 112). Ещё одной важной прерогативой российского монарха в законодательной сфере необходимо считать единоличный «почин» в пересмотре Основных государственных законов (глава 1, статья 8). И, наконец, статья 87 давала право Николаю II принимать чрезвычайные постановления в период между созывами Государственной Думы, чем он пользовался довольно часто. Однако постепенно злоупотребление данной статьёй ослабевало ${ }^{35}$. Для полноты картины в характеристике законодательной власти следует отметить такую важную функцию российского парламента, как обсуждение и утверждение государственного бюджета - однако здесь имелись определённые ограничения (глава 10, статьи 114-118).

Исполнительная власть российского правителя фактически осталась неограниченной. В главе 11 говорится о Председателе Совета Министров, Министрах и их подчинённых, которые были ответственны непосредственно только перед императором (статья 123). Он мог их назначать на должность или увольнять, мало считаясь или не считаясь вообще с мнением Государственной Думы. Если прибавить ко всему выше сказанному возможность императора в любой момент распускать нижнюю палату российского парламента (статья 105), то напрашивается вывод о том, что российский монарх имел достаточно широкие полномочия в сфере исполнительной власти. Сторонники точки зрения об ограничении власти императора в исполнительном плане часто апеллируют к статье 108, закрепившей право «интерпелляции», т.е. наличия у Государственного Совета и Государственной Думы права «потребо-

${ }^{35}$ Миронов Б. Н. Социальная история России периода империи (XVIII начало XX в.): В 2 т. Т. 2. С. 156-157. вать от любого министра официального ответа на свой запрос» ${ }^{36}$. Однако это право фактически министров ни к чему не обязывало.

Касательно судебной власти, по статье 22 она «осуществляется от имени Государя Императора установленными законом судами, решения коих приводятся в исполнение именем Императорского Величества». Однако статья 17 фактически подтвердила с согласия Николая II принцип несменяемости судей, имевший место в Российской империи, начиная со второй половины XVIII века ${ }^{37}$.

Большое значение в характеристике политической системы Российской империи начала XX века имеет глава 8 «О правах и обязанностях российских подданных». Согласно её содержанию у российских подданных существовали всего две обязанности: плата налогов и «защита Престола и Отечества» (статьи 70, 71). При этом они получили достаточно широкий круг прав и свобод: неприкосновенность жилища (статья 75); свобода местожительства, выбора занятий, приобретения и отчуждения имущества, выезда за границу (статья 76); право на собственность (статья 77); право устраивать собрания (статья 78); свобода слова и печати (статья 79); право образовывать общества и союзы (статья 80); свобода веры (статья 81). Однако многие из этих прав и свобод были ограничены временными правилами, указами, положениями и постановлениями, изданными ранее или в данный период (например, Положение о мерах к охранению государственного порядка и общественного спокойствия от 14 августа 1881 года, Положение о паспортах и видах на жительство 1895 г., указы «О временных правилах о повременных изданиях» от 24 ноября 1905 г., «О временных правилах об обществах и союзах» от 4 марта 1906 г. и др.).

Исходя из современных представлений в теории государства и права о форме правления, современные монархии подразделяются на два вида - дуалистические и парламентарные: «Характерной особенностью дуалистической монархии является формально-юридическое разделение государственной власти между монархом и парламентом.

36 Леонтович В. В. История либерализма в России. 17621914. С. 455; Пайпс Р. Русская революция. Ч. 1. С. 178.

37 Леонтович В. В. История либерализма в России. 17621914. C. $457-458$. 


\section{Политика и общество 1 (109) • 2014}

Исполнительная власть находится непосредственно в руках монарха. Законодательная - у парламента. Последний, однако, фактически подчиняется монарху. Парламентарная монархия отличается тем, что статус монарха формально и фактически ограничен во всех сферах осуществления государственной власти. Законодательная власть полностью принадлежит парламенту. Исполнительная правительству, которое несет ответственность за свою деятельность перед парламентом. ... Парламентарные монархии в научной литературе зачастую именуют конституционными монархиями» ${ }^{38}$.

Опираясь на всё выше сказанное и делая общий вывод о форме правления Российской империи начала XX века, можно заключить, что Россия в обозначенный период являлась дуалистической монархией, причем переход к последней был осуществлён не только де-юре, но и де-факто. Это не означает, что Российское государство достигло конечной цели политической модернизации, но дело сдвинулось с мёртвой точки: российская монархия стала постепенно сдавать свои позиции, сделав один из первых, но достаточно значимых шагов на пути формирования основ правового государства и гражданского общества.

Экономическая модернизация, являвшаяся локомотивом модернизационных преобразований в Российской империи на протяжении XVIII-XIX веков $^{39}$, в начале прошлого столетия стала отходить на второй-третий планы во внутренней политике Николая II. Связано это было, в первую очередь, с большей актуальностью политических и социальных преобразований, которая обозначилась во время Первой русской революции. В экономической сфере Россия уже добилась определённых результатов, что подтверждается небывалым промышленным ростом во время экономического подъёма второй половины 1890-х гг. Последний был обусловлен железнодорожным строительством, интенсивно начавшимся в Российском государстве

${ }^{38}$ Марченко М. Н. Теория государства и права: Учебник. 2-е изд., перераб. и доп. М.: ТК Велби, Изд-во Проспект, 2004. C. 305 .

${ }^{39}$ Самохин К. В. Модернизация Российской империи в пореформенный период; Самохин К. В. Процессы модернизации в послепетровской России XVIII века; Самохин К. В. Процессы российской модернизации в конце XVIII - первой половине ХІХ веков; Самохин К. В. Северная война: первый опыт российской модернизации. в 60-е гг. XIX в. и активно проводившимся в два последующих десятилетия ${ }^{40}$.

Российская экономика к началу XX века уже во многом подчинялась рыночным законам и тенденциям развития, в том числе и общемировым экономическим циклам. В итоге её мощный подъём сменился спадом и последовавшей за ним депрессией в 1901-1909 гг. Основными причинами этого спада были «сокращение железнодорожного строительства и связанных с ним заказов, изменение условий мирового денежного рынка, уменьшение иностранных капиталовложений, накопление на складах крупных запасов сырья и топлива в ходе предыдущего бума», а также данное явление можно обусловить «изменениями в торгово-промышленной политике правительства, исчерпанностью внутренних резервов промышленности, позволивших в предшествующие годы дать известный прирост» ${ }^{41}$. Не последнюю роль среди факторов, предопределивших депрессию 1904-1909 гг., сыграли события, имевшие место в период Первой русской революции. Кроме сокращения промышленного производства, которое, кстати, характеризовалось неоднозначностью тенденций, особенностью данного экономического спада была реструктуризация производства, впоследствии имевшая большое значение в период нового подъёма, обозначившегося в 1909-1914 гг.

Главные причины предвоенного экономического бума объясняют такие факторы, как «перестройка промышленности в условиях кризиса, часто повторяющиеся в эти годы высокие урожаи (1909, 1910, 1912, 1913), “успокоение” политической ситуации, достигнутая финансовая стабилизация, увеличение казённых заказов в связи с перевооружением армии и флота, развитие городского строительства, рост массового потребительского спроса как результат революционных завоеваний, приведших к повышению заработной платы рабочих (примерно на 20\%) и отмене

\footnotetext{
${ }^{40}$ Самохин К. В. Модернизация Российской империи в пореформенный период. С. 151-152.

${ }^{41}$ История России XX - начала XXI века / А. С. Барсенков, А. И. Вдовин, С. В. Воронков; под ред. Л. В. Милова. М.: Эксмо, 2006. С. 37; Новейшая история Отечества. XX век: Учеб. для студентов вузов: В 2 т. Т. 1. / Под ред. А. Ф. Киселёва, Э. М. Щагина. М.: Гуманит. Изд. Центр ВЛАДОС, 1998. C. 39.
} 
выкупных платежей крестьянства» ${ }^{42}$. Нельзя скидывать со счетов и столыпинскую аграрную реформу, которая также внесла свою лепту в экономические модернизационные преобразования. Из этого перечня видно, что русско-японская война 1904-1905 гг., показавшая низкий уровень боеспособности русских войск и явившаяся одним из главных факторов, вызвавших Первую русскую революцию, может расцениваться как основное событие из ряда причин, предопределивших экономический подъём 1909-1914 гг. и дальнейшее развитие экономики России в русле модернизации.

Проходившая в предвоенный период индустриализация Российской империи характеризовалась ростом промышленного производства, повышением уровня грамотности кадров в промышленности, концентрацией производства и пролетариата, значительным развитием кредитно-банковской системы, монополизацией промышленности, складыванием финансового капитала, привлечением иностранных инвестиций. Однако предвоенный экономический подъём не имел такого большого значения для модернизации российской экономики, как экономический бум второй половины 1890-х гг. В начале XX века уже отсутствовало интенсивное железнодорожное строительство; не произошло каких-либо радикальных изменений в отраслевой структуре российской промышленности; имеющиеся в распоряжении банков денежные средства, как правило, не шли на финансирование производства; сократились внешние займы, в результате чего промышленность не получила необходимых ей инвестиций; «скудные внутренние накопления в небольших количествах направлялись казной на финансирование столыпинской аграрной реформы и военных программ, а главное - на традиционную поддержку дворянства» ${ }^{43}$.

Исходя из выше сказанного, можно сделать вывод о том, что экономическая модернизация Российской империи в начале XX века стала постепенно выходить из круга первоочередных задач в политике российских императоров. В большей степени она шла уже по инерции в этот период, что объясняет сокращение её темпов, по сравнению с политиче-

\footnotetext{
${ }^{42}$ История России XX - начала XXI века. С. 38

${ }^{43}$ История России XX - начала XXI века. С. 38-62.
}

скими и социальными процессами перехода России от аграрного общества к индустриальному.

Социальная модернизация России в начале $\mathrm{XX}$ века была логическим продолжением тенденций, имевших место во второй половине XIX столетия. Основными реформами в этом направлении следует считать отмену крепостного права в 1861 г. и перевод временнообязанных крестьян на обязательный выкуп в 1881 г. Главной проблемой и особенностью проходящих в России урбанизации и усиления социальной мобильности было сохранение корпоративного вида крепостного права для большинства российского населения, в то время как государственный и частный были уже уничтожены ${ }^{44}$. В начале прошлого века благодаря стараниям С. Ю. Витте указанная проблема стала решаться практически. В 1902 г. под его председательством было создано Особое совещание о нуждах сельскохозяйственной промышленности, которое в целом разработало основные мероприятия, получившие впоследствии название «столыпинская аграрная реформа».

Предшествовала реформе отмена выкупных платежей, последовавшая 3 ноября 1905 г. (с вводом в действие с 1 января 1907 г.). Тогда же Крестьянскому банку были предоставлены широкие полномочия, которые должны были помочь крестьянам увеличить свою земельную собственность, так как проблемы перенаселенности и нехватки земли в Европейской части России были как никогда актуальны. Этими мероприятиями правительство Николая II надеялось сбить накал борьбы в период Первой русской революции, но все подобные ожидания оказались тщетными ${ }^{45}$.

Потому П. А. Столыпин, назначенный в апреле 1906 г. министром внутренних дел, а в июле - Председателем Совета министров, приступил к своим аграрным преобразованиям. Нельзя сказать, что аграрная реформа была вызвана только событиями Первой русской революции, так как её необходимость была понятна правящим кругам

\footnotetext{
${ }^{44}$ Самохин К. В. Социальная модернизация России во второй половине XIX - первые годы XX веков // Исторические, философские, политические и юридические науки, культурология и искусствоведение. Вопросы теории и практики. Тамбов: Грамота, 2013. № 5 (31). Ч. 2. С. 169-171.

45 Леонтович В. В. История либерализма в России. $1762-$ 1914. C. 269.
} 


\section{Политика и общество 1 (109) • 2014}

ещё в 90-е гг. ХХ века, но революционные потрясения, безусловно, сыграли важную роль в ускорении начала её проведения ${ }^{46}$.

Как известно, Столыпин решил воспользоваться 87-й статьёй Основных законов Российской империи для того, чтобы приступить к реализации своих замыслов. Главным актом реформы был указ, изданный 9 ноября 1906 г. и разрешавший «крестьянам-домохозяевам выходить из общины и укреплять землю в личную частную собственность» (данный указ был принят в виде закона только Третьей Думой в 1910 г. $)^{47}$. Именно он фактически и должен был уничтожить корпоративный вид крепостного права для крестьянства в виде общины. Последняя усердно сохранялась при Александре III, так как существовало «убеждение, что община в деревне - некая стабилизирующая сила, укрепляющая авторитет большака, препятствующая крестьянскому анархизму и образованию политически неблагонадёжного безземельного пролетариата» ${ }^{48}$. Между тем, она через земельные переделы, чересполосицу, круговую поруку очень сильно сдерживала темпы развития сельского хозяйства, а также, по мнению Витте, обуславливала низкую налогоспособность крестьян ${ }^{49}$. Другим важным государственным актом в осуществлении аграрной реформы стал Закон о проведении землеустроительных работ, изданный 29 мая 1911 г. Основной смысл этого закона заключался в создании отрубного и хуторского хозяйства через ликвидацию чересполосицы.

Особое место среди мер столыпинской агарной реформы занимала переселенческая политика, главной целью которой была ликвидация аграрной перенаселенности Европейского центра России. Крестьяне получили возможность обосноваться на свободных землях Сибири, Дальнего Востока, Алтая и Средней Азии. Однако результаты этой меры были довольно скромными из-за недостаточной финансовой поддержки правительства, отсутствия дорог, отдалённости территорий, плохой организации переезда.

\footnotetext{
${ }^{46}$ Новейшая история Отечества. ХХ век: Учеб. для студентов вузов: В 2 т. Т. 1. С. 52-53.

${ }^{47}$ Новейшая история Отечества. ХХ век: Учеб. для студентов вузов: В 2 т. Т. 1. С. 55-56.

${ }^{48}$ Пайпс Р. Русская революция. Ч. 1. С. 112.

${ }^{49}$ Новейшая история Отечества. ХХ век: Учеб. для студентов вузов: В 2 т. Т. 1. С. 52.
}

Такой же характер носили и итоги столыпинской агарной реформы. В целом их следует обозначить как неудачные: «Неудача столыпинской реформы резко оттеняет трагизм социально-экономического развития России. Волею судьбы оказавшись в самых неблагоприятных природно-климатических и географических условиях среди основных европейских стран, великорусский социум ещё в Средневековье создал механизмы своего выживания и развития в лице крепостничества и сохранения общины. В XIX в. с активным ростом промышленности роль этих механизмов неуклонно ослаблялась, набирая отрицательные качества. Поиск новых компенсационных механизмов в силу развития в стране капитализма был ориентирован на опыт западной цивилизации, но в начале XX в. он оказался неудачным» ${ }^{50}$.

Таким образом, процессы урбанизации и роста социальной мобильности российского населения начала XX века во многом сохраняют тенденции, наметившиеся во второй половине XIX столетия: уровень социальной мобильности существенно повышался, а рост городского населения происходил достаточно вялыми темпами ${ }^{51}$ В итоге, можно сделать вывод о том, что продолжение социальной модернизации российского общества в начале XX века в целом оказалось неудачным.

Духовная модернизация, характеризующаяся возникновением мультикультурализма как основы менталитета населения, в Российской империи по-прежнему носила зачаточный характер. Если для высших слоев российского общества её следует признать уже свершившимся фактом, то коллективное сознание низших слоёв населения крестьянства и горожан - в начале XX века определялось следующими установками: патриархальные отношения (или патернализм), религиозность, принципы уравнительного землепользования (или социальная справедливость), монархизм, общинный коллективизм, сочетающийся с индивидуальными началами ${ }^{52}$. Если какие-либо изменения в

\footnotetext{
${ }^{50}$ История России XX - начала XXI века. С. 154.

${ }^{51}$ Самохин K. B. Социальная модернизация России во второй половине XIX - первые годы XX веков.

${ }^{52}$ Кожевникова Л. М. Роль крестьянской общины в аграрной истории и судьбе России // Исторические, философские, политические и юридические науки, культурология и искусствоведение. Вопросы теории и практики. Тамбов: Грамота,
} 
этом плане и имели место, то в большинстве случаев они носили начальный характер.

Патернализм (или патриархальность) выходил из характера русской крестьянской семьи, в которой власть безраздельно принадлежала большаку: «Уклад русского крестьянского двора воспроизводил простую авторитарную модель, при которой все права над людьми и их имуществом принадлежали одному человеку - «большаку», или хозяину» ${ }^{53}$. Благодаря отмене крепостного права и другим либеральным реформам 60-х 70-х гг. XIX века положение дел в этом аспекте менялось, но незначительно: «Огромная смертность, учащавшиеся попытки уклониться от рождения детей или отказ от детей, уже рождённых, «падение семейных нравов», женское эмансипированное движение в городах и «бабий бунт»в деревне, непокорность взрослых детей и ослабевавшая родительская власть, умножавшиеся крестьянские семейные разделы - всё это говорило об обесценивании вековых заповедей семейной жизни, об усиливающемся её разладе. Разлад был замечен всеми и стал объектом критики, самокритики русского общества, всё более осознававшего необходимость обновления» ${ }^{54}$.

Степень религиозности и монархизма также имела тенденцию к снижению. Это стало следствием распространения образования, роста миграционных процессов, развития промыслов и отходничества, русско-японской войны и Первой русской революции. Однако к 1914 г. она в целом находилась на довольно высоком уровне ${ }^{55}$.

Принципы уравнительного землепользования и общинного коллективизма были характерными чертами жизни русского крестьянства практически на всём протяжении существования Российского государства. Данный факт объясняется тем, что «община была сообществом крестьян, совместно

2011. № 7 (13). Ч. 3; Поршнева О. С. Менталитет и социальное поведение рабочих, крестьян и солдат России в период Первой мировой войны (1914 - март 1918). Екатеринбург, 2000. С. 91-102.

${ }^{53}$ Пайпс Р. Русская революция. Ч. 1. С. 106.

${ }^{54}$ Демографическая модернизация России, 1900-2000 / Под ред. А. Г. Вишневского. М.: Новое издательство, 2006. С. 62.

${ }^{55}$ Самохин К. В. Тамбовское крестьянство в годы Первой мировой войны (1914 - февраль 1917 гг.): Монография. СПб.: Нестор, 2004. С. 80. владеющих общинной землёй. Эта земля, поделённая на полосы, время от времени перераспределялась между членами общины. Земельные переделы, производившиеся примерно каждые десять-двенадцать лет в зависимости от местных обычаев, имели целью привести земельные наделы в соответствие с теми изменениями, которые произошли во дворах по причине смертей, рождений и ухода домочадцев. В этом заключалась основная функция общины и её отличительная характеристика» ${ }^{56}$. Эти принципы также подверглись незначительным трансформациям, о чём свидетельствуют итоги столыпинской аграрной реформы.

Если говорить о городском населении и его подверженности указанным установкам в ментальном плане, то нельзя не согласиться с доводом Б. Н. Миронова: не только городской образ жизни и стиль мышления влияли на крестьянскую среду, но и усилившийся процесс урбанизации нес в город образцы сельского быта, стиля жизни и системы ценностей ${ }^{57}$.

Исходя из приведённого анализа, можно сделать вывод о том, что японский вариант модернизации не соответствовал российским реалиям. Сложившаяся система ценностей (в первую очередь в крестьянской среде) не позволяла полностью завершить построение правового государства и гражданского общества, а также установить законченную модель модернизации в социальном плане. Религиозность, общинный коллективизм и уравнительное землепользование не предполагали возможностей для широких заимствований у других народов. Именно в этом кроется, на наш взгляд, основная причина столь затяжного характера перехода Российской империи от аграрного общества к индустриальному.

Таким образом, модернизация России и в начале прошлого столетия продолжала соответствовать общим тенденциям, намеченным в XVIIIXIX веках. Военный фактор, и в частности русско-японская война 1904-1905 гг., по-прежнему играл роль «Вызова» к российской (славянской) цивилизации при построении основ индустриального общества. Наибольшую значимость в этот период приобрела политическая модернизация,

\footnotetext{
${ }^{56}$ Пайпс Р. Русская революция. Ч. 1. С. 110.

${ }^{57}$ Миронов Б. Н. Социальная история России периода империи (XVIII - начало XX в.): В 2 т. Т. 1. С. 340-345.
} 


\section{Политика и общество 1 (109) • 2014}

приведшая к созданию дуалистической монархии. Рост социальной мобильности и урбанизация русского населения в целом не получили законченного выражения, что было связано, в том числе, с низкой эффективностью столыпинской аграрной реформы. Экономическая модернизация в политике Николая II ушла на второй план в силу большей актуальности политико-социальных преобразований и определённых успехов, достигнутых в этом плане к началу XX века. Складывание мультикультурализма, базирующегося на общечеловеческих ценностях, находилось лишь только в стадии становления. В итоге следует констатировать сохранение неорганичного характера российской модернизации ${ }^{58}$, что требовало появления новых «Вызовов», следующим из которых стала Первая мировая война.

\section{Библиография:}

1. Безгин В.Б. Русская деревня конца XIX начала XX века: грани крестьянской девиантности (Часть 1) // NB: Исторические исследования. 2012. № 1. C. 120-167. DOI: 10.7256/2306-420X.2012.1.266. URL: http:// www.e-notabene.ru/hr/article_266.html (дата обращения: 26.08.2013).

2. Безгин В.Б. Русская деревня конца XIX - начала XX века: грани крестьянской девиантности (Часть 2) // NB: Исторические исследования. 2012. № 2. C. 149-190. DOI: 10.7256/2306-420X.2012.2.302. URL: http://www.e-notabene.ru/hr/article_302.html (дата обращения: 26.08.2013).

3. Буранчин А. М. Традиционное общество и модернизация: теоретико-методологический аспект. URL: $\quad$ http://against-postmodern.org/buranchintraditsionnoe-obshchestvo-i-modernizatsiyateoretiko-metodologicheskii-aspekt (дата обращения: 26.08.2013).

4. Васильев Л. С. История Востока: В 2 т.: Учеб. по спец. «История». М.: Высш. шк., 1994.

5. Высочайше утверждённые Основные государственные законы 23 апреля 1906 г. URL: http:// www.hist.msu.ru/ER/Etext/apr1906.htm (дата обращения: 26.08.2013).

${ }_{58}$ Красильщиков В. А. Модернизация и Россия на пороге XXI века // Вопросы философии. 1993. № 7. С. 47.
6. Елисеефф В., Елисеефф Д. Японская цивилизация / Пер. с франц. И. Эльфонд. Екатеринбург: У-Фактория, 2005. 528 с.

7. Демографическая модернизация России, 19002000 / Под ред. А. Г. Вишневского. М.: Новое издательство, 2006. 608 с.

8. История России XX - начала XXI века / А. С. Барсенков, А. И. Вдовин, С. В. Воронков; под ред. Л. В. Милова. М.: Эксмо, 2006. 960 с.

9. Керсновский А. А. История русской армии в 4 томах. М.: Голос, 1992. Т. 3. 352 с.

10. Кожевникова Л. М. Роль крестьянской общины в аграрной истории и судьбе России // Исторические, философские, политические и юридические науки, культурология и искусствоведение. Вопросы теории и практики. Тамбов: Грамота, 2011. № 7 (13). Ч. 3. С. 85-90.

11. Костюк К. Н. Архаика и модернизм в российской культуре. URL: http://www.nir.ru/sj/sj/sj3-4-99kost. html (дата обращения: 26.08.2013).

12. Красильщиков В. А. Модернизация и Россия на пороге XXI века // Вопросы философии. 1993. № 7. С. 40-56.

13. Леонтович В. В. История либерализма в России. 1762-1914. М.: Русский путь; Полиграфресурсы, $1995.550 \mathrm{c}$.

14. Марченко М. Н. Теория государства и права: Учебник. 2-е изд., перераб. и доп. М.: ТК Велби, Изд-во Проспект, 2004. 640 с.

15. Миронов Б. Н. Социальная история России периода империи (XVIII - начало XX в.): В 2 т. СПб.: Изд-во «Дмитрий Буланин», 2000.

16. Модернизация России и Европа: материалы круглого стола, проведенного 18.03.2004. URL: http://www.zlev.ru/41_40.htm (дата обращения: 26.08.2013).

17. Новейшая история Отечества. XX век: Учеб. для студентов вузов: В 2 т. Т. 1. / Под ред. А. Ф. Киселёва, Э. М. Щагина. М.: Гуманит. Изд. Центр ВЛАДОС, 1998. 496 с.

18. Пайпс Р. Русская революция. Ч. 1. М.: РОССПЭН, 1994. 399 c.

19. Поршнева О. С. Менталитет и социальное поведение рабочих, крестьян и солдат России в период Первой мировой войны (1914 - март 1918). Екатеринбург, 2000. 416 с.

20. Самохин К. В. Многоликая война // Исторические, философские, политические и юридические науки, культурология и искусствоведение. Во- 
просы теории и практики. Тамбов: Грамота, 2009. № 2 (3). Ч. 2. С. 81-83.

21. Самохин К. В. Модернизация Российской империи в пореформенный период // Альманах современной науки и образования. Тамбов: Грамота, 2013. № 5 (72). С. 149-155.

22. Самохин К. В. Процессы модернизации в послепетровской России XVIII века // Современные исследования социальных проблем (электронный научный журнал). Красноярск: Научно-инновационный центр, 2012. №9 (17). URL: http://sisp. nkras.ru/e-ru/issues/2012/9/samokhin.pdf (дата обращения: 26.08.2013).

23. Самохин К. В. Процессы российской модернизации в конце XVIII - первой половине XIX веков

// Современные исследования социальных проблем (электронный научный журнал). Красноярск: Научно-инновационный центр, 2012. №11 (19). URL: http://sisp.nkras.ru/e-ru/issues/2012/11/ samokhin.pdf (дата обращения: 26.08.2013).

24. Самохин К. В. Северная война: первый опыт российской модернизации // Исторические, философские, политические и юридические науки, культурология и искусствоведение. Вопросы теории и практики. Тамбов: Грамота, 2011. № 8 (14). С. $180-185$.

25. Самохин К. В. Социальная модернизация России во второй половине XIX - первые годы XX веков // Исторические, философские, политические и юридические науки, культурология и искусствоведение. Вопросы теории и практики. Тамбов: Грамота, 2013. № 5 (31). Ч. 2. С. 168-172.

26. Самохин К. В. Тамбовское крестьянство в годы Первой мировой войны (1914 - февраль 1917 гг.): Монография. СПб.: Нестор, 2004. 122 с.

27. Самохин К. В. Трансформации крестьянского менталитета в годы Первой мировой войны (на материалах Тамбовской губернии) // Первая мировая война: поиски подходов к исследованию, приглашение к диалогу: Доклады Академии военных наук (военная история). № 5 (23). Саратов, 2006. C. 249-255.

\section{References (transliteration):}

1. Bezgin V.B. Russkaya derevnya kontsa XIX - nachala XX veka: grani krest'yanskoi deviantnosti (Chast' 1)// NB: Istoricheskie issledovaniya. 2012. № 1. C. 120-
167. DOI: 10.7256/2306-420X.2012.1.266. URL: http://www.e-notabene.ru/hr/article_266.html (data obrashcheniya: 26.08.2013).

2. Bezgin V.B. Russkaya derevnya kontsa XIX nachala XX veka: grani krest'yanskoi deviantnosti (Chast' 2) // NB: Istoricheskie issledovaniya. 2012. № 2. C. 149-190. DOI: 10.7256/2306420X.2012.2.302. URL: http://www.e-notabene.ru/hr/article_302.html (data obrashcheniya: 26.08.2013).

3. Buranchin A. M. Traditsionnoe obshchestvo i modernizatsiya: teoretiko-metodologicheskii aspekt. URL: http://against-postmodern.org/buranchin-traditsionnoe-obshchestvo-i-modernizatsiya-teoretiko-metodologicheskii-aspekt (data obrashcheniya: 26.08.2013).

4. Vasil'ev L. S. Istoriya Vostoka: V 2 t.: Ucheb. po spets. «Istoriya». M.: Vyssh. shk., 1994.

5. Eliseeff V., Eliseeff D. Yaponskaya tsivilizatsiya / Per. s frants. I. El'fond. Ekaterinburg: U-Faktoriya, 2005. $528 \mathrm{~s}$.

6. Kersnovskii A. A. Istoriya russkoi armii v 4 tomakh. M.: Golos, 1992. T. 3. 352 s.

7. Kozhevnikova L. M. Rol' krest'yanskoi obshchiny v agrarnoi istorii i sud'be Rossii // Istoricheskie, filosofskie, politicheskie i yuridicheskie nauki, kul'turologiya i iskusstvovedenie. Voprosy teorii i praktiki. Tambov: Gramota, 2011. № 7 (13). Ch. 3. S. 85-90.

8. Kostyuk K. N. Arkhaika i modernizm v rossiiskoi kul'ture. URL: http://www.nir.ru/sj/sj/sj3-4-99kost. html (data obrashcheniya: 26.08.2013).

9. Krasil'shchikov V. A. Modernizatsiya i Rossiya na poroge XXI veka // Voprosy filosofii. 1993. № 7. S. 40-56.

10. Leontovich V. V. Istoriya liberalizma v Rossii. 17621914. M.: Russkii put'; Poligrafresursy, 1995. 550 s.

11. Marchenko M. N. Teoriya gosudarstva i prava: Uchebnik. 2-e izd., pererab. i dop. M.: TK Velbi, Izdvo Prospekt, 2004. 640 s.

12. Mironov B. N. Sotsial'naya istoriya Rossii perioda imperii (XVIII - nachalo XX v.): V 2 t. SPb.: Izd-vo «Dmitrii Bulanin», 2000.

13. Paips R. Russkaya revolyutsiya. Ch. 1. M.: ROSSPEN, 1994. 399 s.

14. Porshneva O. S. Mentalitet i sotsial'noe povedenie rabochikh, krest'yan i soldat Rossii v period Pervoi mirovoi voiny (1914 - mart 1918). Ekaterinburg, 2000. 416 s. 


\section{Политика и общество 1 (109) • 2014}

15. Samokhin K. V. Mnogolikaya voina // Istoricheskie, filosofskie, politicheskie i yuridicheskie nauki, kul'turologiya i iskusstvovedenie. Voprosy teorii i praktiki. Tambov: Gramota, 2009. № 2 (3). Ch. 2. S. 81-83.

16. Samokhin K. V. Modernizatsiya Rossiiskoi imperii $\mathrm{V}$ poreformennyi period // Al'manakh sovremennoi nauki i obrazovaniya. Tambov: Gramota, 2013. № 5 (72). S. 149-155.

17. Samokhin K. V. Protsessy modernizatsii v poslepetrovskoi Rossii XVIII veka // Sovremennye issledovaniya sotsial'nykh problem (elektronnyi nauchnyi zhurnal). Krasnoyarsk: Nauchno-innovatsionnyi tsentr, 2012. №9 (17). URL: http://sisp.nkras.ru/e-ru/issues/2012/9/ samokhin.pdf (data obrashcheniya: 26.08.2013).

18. Samokhin K. V. Protsessy rossiiskoi modernizatsii v kontse XVIII - pervoi polovine XIX vekov // Sovremennye issledovaniya sotsial'nykh problem (elektronnyi nauchnyi zhurnal). Krasnoyarsk: Nauchnoinnovatsionnyi tsentr, 2012. №11 (19). URL: http:// sisp.nkras.ru/e-ru/issues/2012/11/samokhin.pdf (data obrashcheniya: 26.08.2013).
19. Samokhin K. V. Severnaya voina: pervyi opyt rossiiskoi modernizatsii // Istoricheskie, filosofskie, politicheskie i yuridicheskie nauki, kul'turologiya i iskusstvovedenie. Voprosy teorii i praktiki. Tambov: Gramota, 2011. № 8 (14). S. 180-185.

20. Samokhin K. V. Sotsial'naya modernizatsiya Rossii vo vtoroi polovine XIX - pervye gody XX vekov // Istoricheskie, filosofskie, politicheskie i yuridicheskie nauki, kul'turologiya i iskusstvovedenie. Voprosy teorii i praktiki. Tambov: Gramota, 2013. № 5 (31). Ch. 2. S. 168-172.

21. Samokhin K. V. Tambovskoe krest'yanstvo v gody Pervoi mirovoi voiny (1914 - fevral' 1917 gg.): Monografiya. SPb.: Nestor, 2004. 122 s.

22. Samokhin K. V. Transformatsii krest'yanskogo mentaliteta $\mathrm{v}$ gody Pervoi mirovoi voiny (na materialakh Tambovskoi gubernii) // Pervaya mirovaya voina: poiski podkhodov $\mathrm{k}$ issledovaniyu, priglashenie k dialogu: Doklady Akademii voennykh nauk (voennaya istoriya). № 5 (23). Saratov, 2006. S. 249-255. 